\title{
ANALISIS TINGKAT RISIKO CIDERA PEKERJA MENGGUNAKAN METODE RAPID ENTIRE BODY ASSESSMENT (REBA) PADA BAGIAN REACHING \\ DI UNIT WEA VING II ( Studi Kasus di PT. Dan Liris Surakarta )
}

\author{
Edy Joko Susilo, Hari Purnomo, Nancy Okyajati \\ Program Studi Teknik Industri,Fakultas Teknik Sains dan Pertanian \\ Universitas Islam Batik Surakarta \\ Email : edyjoko11.ej@gmail.com
}

\begin{abstract}
Abstrak : PT Dan Liris adalah salah satu Industri yang memproduksi kain. Dalam proses reaching pada pembuatan kain dikerjakan dengan secara manual atau tanpa menggunakan bantuan mesin. Postur kerja karyawan dalam melaksanakan pekerjaannya selalu duduk dan membungkuk dalam waktu yang cukup lama dan berulang-ulang sehingga sering kali pekerja mengeluh karena ada bagian tubuh yang merasa sakit, yaitu di daerah leher, bahu, dan punggung. Tujuan dari penelitian ini untuk mengetahui tingkat risiko cidera pekerja dilihat dari sikap kerja atau postur kerja. Metode yang dapat digunakan untuk menganalisis postur tubuh adalah REBA (Rapid Entire Body Assessment). Metode analisis REBA digunakan secara cepat untuk menilai seluruh postur bagian tubuh dari leher, punggung, lengan, pergelangan tangan, dan kaki seorang pekerja. Hasil dari penelitian ini memperoleh skor REBA dengan nilai 6 setelah ditambah dengan skor aktivitas dari pekerja. Dapat disimpulkan bahwa tingkat risiko yang diperoleh pada postur kerja di bagian reaching berada dalam kategori level action 2 yaitu level risiko sedang dan perlu perbaikan untuk mengurangi risiko cidera pada operator reaching.
\end{abstract}

Kata Kunci : REBA, Postur kerja, Risiko, Weaving, Reaching.

\section{PENDAHULUAN}

Pada masa sekarang pembangunan disektor Industri besar, sedang maupun kecil semakin meningkat. Pembangunan di sektor industri ditujukan untuk memperluas lapangan kerja, kesempatan berusaha dan untuk meningkatkan mutu serta perlindungan bagi tenaga kerja (Catur, 2012). Perlindungan tenaga kerja ditujukan kepada perbaikan upah, syarat kerja, serta jaminan sosial lainnya dalam rangka perbaikan kesejahteraan tenaga kerja.

Ergonomi merupakan studi tentang aspek manusia dalam lingkungan kerja yang ditinjau secara anatomi, fisiologi, psikologi, engineering, manajemen dan perancangan atau design. Peran ergonomi dalam perancangan sangat penting dalam hal meningkatkan keselamatan dan kesehatan kerja (Nurmianto,1996). Proses kerja di lapangan masih banyak terjadi kecelakaan kerja pada pekerja dikarenakan sikap kerja/posisi kerja yang tidak amaliah, melakukan aktivitass yang berulang-ulang dan melakukan peregangan yang salah dan berlebih dapat menyebabkan terjadinya keluhan otot pada pekerja (Tarwaka, 2004). Salah satu keluhan yang menjadi penilaian adalah nyeri pada tulang belakang atau punggung yang di rasakan oleh pekerja.

Di kota solo terdapat berbagai macam Industri khususnya dibidang Industri tekstil. Dari Industri yang bersekala kecil hingga yang besar, diantaranya PT Dan Liris . Industri yang membuat produk kain ini terdiri dari beberapa unit proses spinning, weaving, finishing dan printing.

Pada unit proses weaving di PT Dan Liris terbagi menjadi beberapa bagian yaitu gudang bahan baku, warping, sizing, reaching, taying, lom, inspecting. Peneliti hanya berfokus bagian proses kerja reaching pada unit weaving II. Pencucukan / reaching adalah proses persiapan 
pertenunan benang lusi setelah melewati proses penganjian kemudian di proses leasing atau pemisahan benang atas dengan benang bawah lalu dicucuk/proses pencucukan.

Sikap kerja di PT. Dan Liris pada bagian prepare produksinya, yang ada di reaching atau pencucukan. Dalam proses reaching dilakukan dengan manual atau tanpa menggunakan bantuan mesin. Postur kerja karyawan dalam melaksanakan pekerjaannya selalu duduk dan membungkuk dalam waktu yang cukup lama dan berulang-ulang. Proses kerja seperti itu dilakukan selama 8 jam kerja dengan 1 jam istirahat, sehingga sering kali pekerja mengeluh karena ada bagian tubuh yang merasa sakit, yaitu di daerah leher, bahu, dan punggung.

Berdasarkan latar belakang diatas peneliti tertarik untuk melakukan analisis tingkat risiko cidera terhadap postur kerja pekerja pada bagian reaching di unit weaving II.

\section{METOD PENELITIAN}

Metode yang dilakukan dalam penelitian ini menggunakan metode kulitatif dengan melakukan observasi langsung ke tempat proses reaching unit weaving II PT Dan Liris yang beralamatkan di Kelurahan Banaran, Kecamatan Grogol, Kabupaten Sukoharjo 57193 Jawa Tengah, Indonesia. Pengumpulan data dalam penelitian ini adalah dengan cara merekam aktivitas pekerja di reaching dengan menggunakan foto atau video lalu dilakukan penentuan sudut dari bagian tubuh operator tersebut. Metode analisis data yang dipakai dalam penelitian ini adalah dengan menggunakan REBA (Rapid Entire Body Assessment).

Rapid Entire Body Assessment adalah sebuah metode yang dikembangkan dalam bidang ergonomi dan dapat digunakan secara cepat untuk menilai posisi kerja atau postur leher, punggung, lengan, pergelangan tangan dan kaki seorang operator (Wisanggeni, 2010). Berikut proses pengolahan data yang dilakukan peneliti dalam penelitian ini:

1) Aktivitas Operator di Bagian Reaching

Data aktivitas di bagian reaching diperoleh dengan menggunakan foto atau alat perekam gambar. Data ini akan digunakan untuk mengetahui postur kerja dari operator untuk dicari tingkat risiko cideranya.

2) Data Keluhan Operator Berdasarkan Nordic Body Map

Nordic Body Map digunakan untuk mengetahui gambaran keluhan rasa sakit yang dirasakan oleh pekerja menggunakan kuesioner. Kuesioner Nordic Body Map merupakan kuesioner yang paling sering dipakai untuk mengetahui ketidaknyamanan pada pekerja dan kuesioner ini sudah terstandarisasi dan tersusun rapi (Kroemer, 1994). Pada pengumupulan data keluhan operator reaching saat melakukan aktivitas yaitu untuk mengetahui keluhankeluhan ynag dirasakan oleh operator dengan cara melakukan wawwancara dan menyebar kuesioner nordic body map pada operator reaching.

3) Penilaian Sudut Postur Tubuh Pekerja

Setelah data dikumpulkan kemudian diolah agar dapat dianalisis. Penilaian sikap kerja diperoleh dari hasil poto atau gambar postur kerja dari operator dengan melakukan perhitungan besar sudut pada postur kerja operator yang didapat. Pada metode REBA segmen tubuh dibagi menjadi dua kelompok tabel yaitu tabel A dan tabel B.

4) Penilaian Grub A

Penilaian didapatkan dari tabel A, setelah didapatkan nilai dari tabel A kemudian dijumlahkan dengan skor untuk berat beban yang diangkat seperti pada gambar dibawah sehingga didapatkan skor total A. 


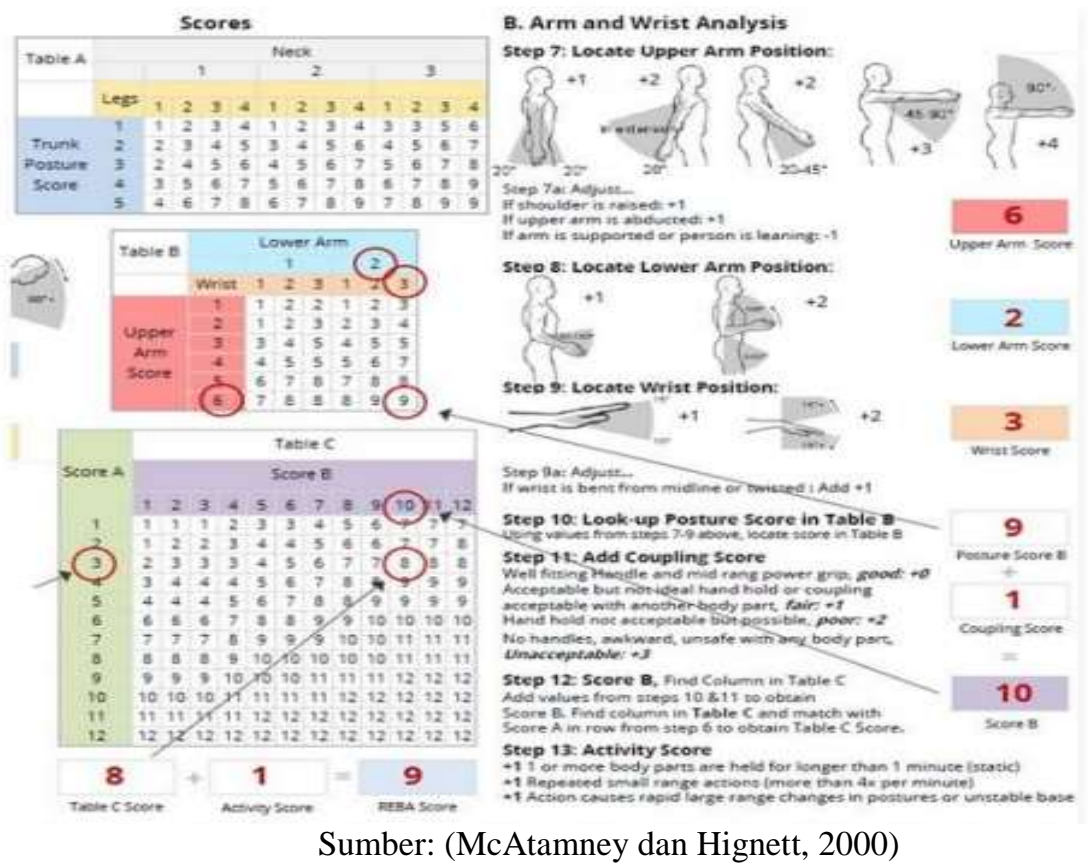

Gambar 1. Tabel A

5) Penilaian Grub B

Penilaian didapatkan dari tabel B, setelah didapatkan nilai dari tabel B kemudian dijumlahkan dengan skor untuk coupling atau genggaman seperti pada gambar dibawah sehingga didapatkan skor total B.

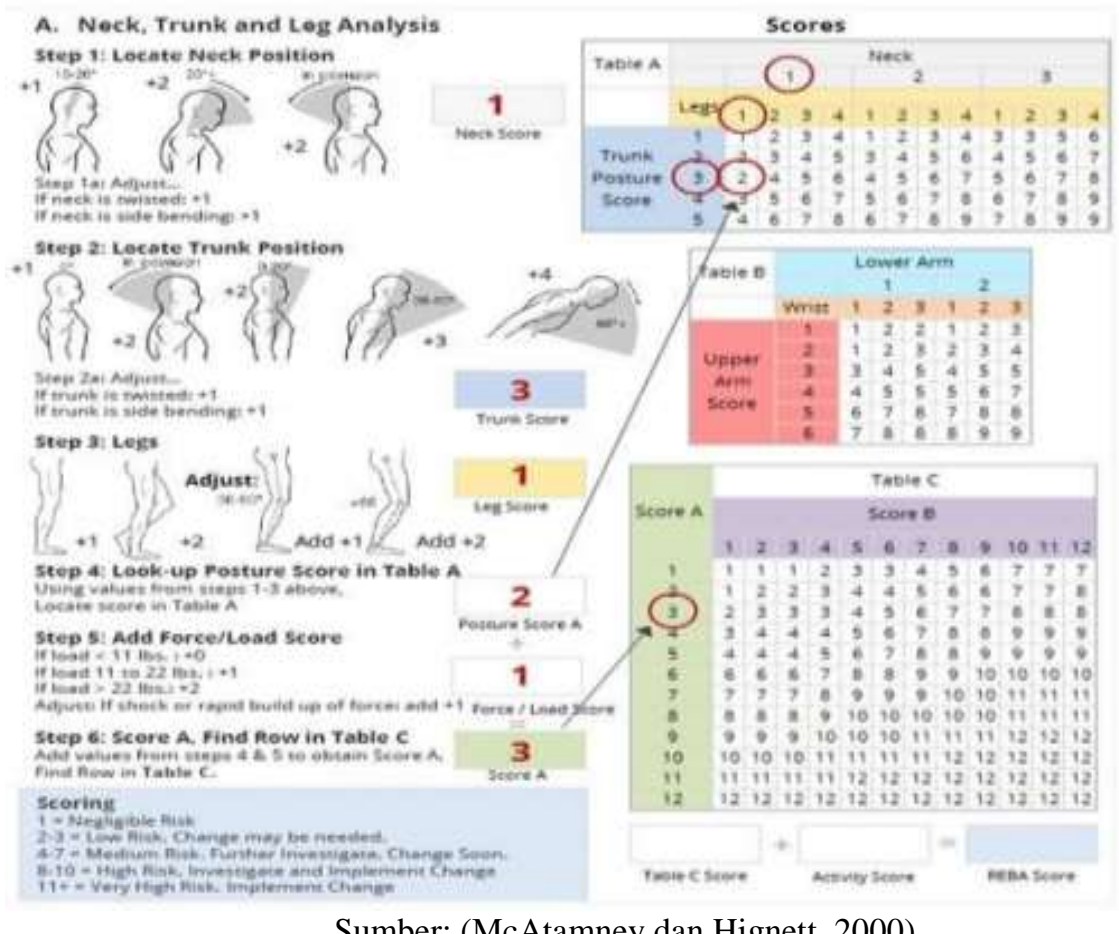

Gambar 2. Tabel B

6) Penentuan Skor Pada Tabel C

Hasil skor yang telah diperoleh dari skor total A dan B digunakan untuk mencari skor dari tabel $\mathrm{C}$, setelah didapatkan skor tabel $\mathrm{C}$ lalu dijumlahkan dengan skor untuk aktivitas 
seperti pada tabel dibawah sehingga diperoleh nilai REBA untuk diketahui tingkat risiko

cidera

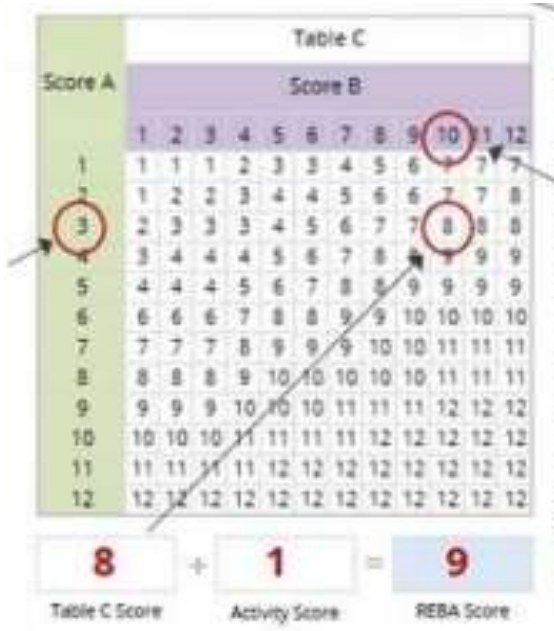

dari

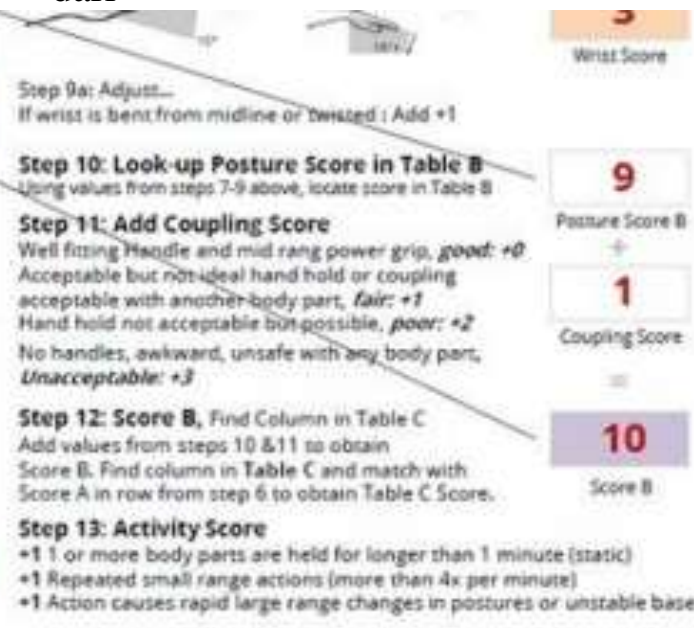

operator.

7) Penilaian Tingkat Risiko

Sumber: (McAtamney dan Hignett, 2000)

Gambar 3. Tabel C

Dari nilai REBA yang diperoleh dapat diketahui level risiko dan perlu atau tidaknya tindakan yang dilakukan untuk perbaikan dapat dilihat pada gambar berikut.

\begin{tabular}{|c|c|c|c|}
\hline Action Level & Skor REBA & Level Resiko & Tindakan Perbaikan \\
\hline 0 & 1 & Bisa Diabaikan & Tidak perlu \\
\hline 1 & $2-3$ & Rendah & Mungkin perlu \\
\hline 2 & $4-7$ & Sedang & Perlu \\
\hline 3 & $8-10$ & Tinggi & Perlu segera \\
\hline 4 & $11+$ & Sangat Tinggi & Perlu saat ini juga \\
\hline
\end{tabular}

Sumber: (McAtamney dan Hignett, 2000)

Gambar 4. Tabel Tingkat Risiko

\section{HASIL DAN PEMBAHASAN}

\section{Aktivitas Operator Di Bagian Reaching}

Proses reaching untuk membuat kain yang dilakukan oleh operator kesehariannya adalah duduk pada kursi reaching dan melakukan proses reaching atau menganyam benang. Alat dan bahan yang digunakan dalam proses reaching yaitu pengait benang, sisir, benang, dropper, gun dan heal frame. Proses reaching dilakukan dengan cara memasukkan benang kelubang dropper dan gun yang telah ditentukan sesuai rumus anyaman yang ada di buku reaching. Operator menoleh kekanan dan kiri untuk mengambil benang dan memasukan benang ke lubang. Aktivitas postur kerja pada operator bagian reaching dapat dilihat pada gambar. 


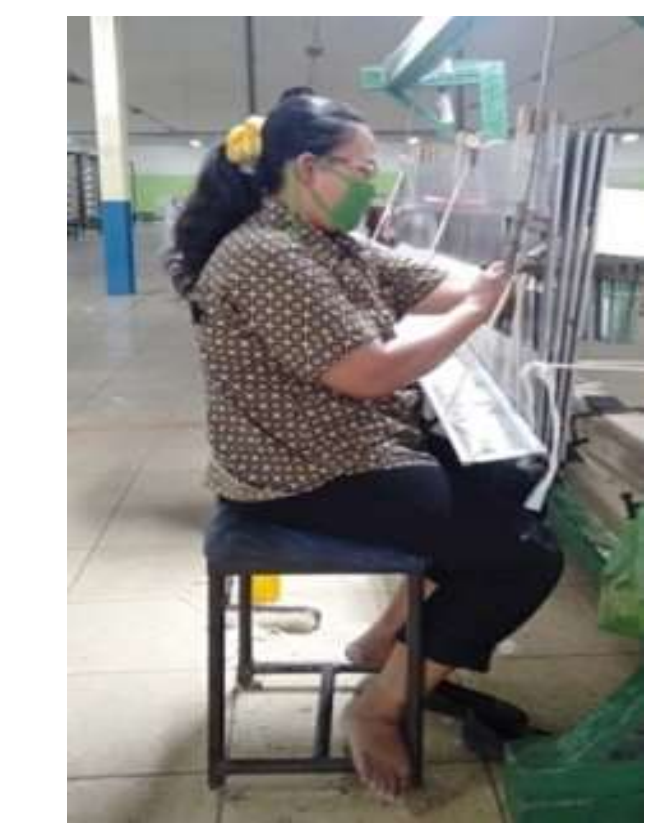

Sumber: Data dokumentasi postur kerja reaching

Gambar 5. Aktivitas kerja di reaching

\section{Data Keluhan Operator Berdasarkan Nordic Body Map}

Saat melakukan proses reaching terdapat keluhan yang dirasakan oleh operator. Untuk mengetahui keluhan yang dirasakan oleh operator dari semua aktivitas kerja dilakkan menggunakan analisis. Analisis yang digunakan untuk mengetahui bagian keluhan yang dirasakan oleh operator yaitu menggunakan kuesioner Nordic Body Map terhadap operator yang berjumlah 4 orang dalam satu shift pada bagian reaching. Kuesioner yang disusun berupa pertanyaan mengenai segmen tubuh di bagian mana yang mengalami keluhan sebeluh dan sesudah melakukan aktivitas kerja reaching. Hasil dari kuesioner Nordic body map dapat dilihat pada tabel.

Tabel 1. Nordic Body Map

\begin{tabular}{|c|l|r|}
\hline No. & Jenis Keluhan & Persentase \\
\hline 0 & Sakit/kaku di leher bagian atas & $62,50 \%$ \\
\hline 1 & Sakit/kaku di leher bagian bawah & $50,00 \%$ \\
\hline 2 & Sakit di bahu kiri & $75,00 \%$ \\
\hline 3 & Sakit di bahu kanan & $75,00 \%$ \\
\hline 4 & Sakit pada lengan atas kiri & $63,50 \%$ \\
\hline 5 & Sakit di punggung & $63,50 \%$ \\
\hline 6 & Sakit pada lengan atas kanan & $75,00 \%$ \\
\hline 7 & Sakit pada pinggang & $37,50 \%$ \\
\hline 8 & Sakit pada bokong & $37,50 \%$ \\
\hline 9 & Sakit pada pantat & $37,50 \%$ \\
\hline 10 & Sakit pada siku kiri & $25,00 \%$ \\
\hline 11 & Sakit pada siku kanan & $25,00 \%$ \\
\hline 12 & Sakit pada lengan bawah kiri & $50,00 \%$ \\
\hline 13 & Sakit pada lengan bawah kanan & $50,00 \%$ \\
\hline 14 & Sakit pada pergelangan tangan kiri & $50,00 \%$ \\
\hline 15 & Sakit pada pergelangan tangan kanan & $50,00 \%$ \\
\hline 16 & Sakit pada tangan kiri & $50,00 \%$ \\
\hline
\end{tabular}




\begin{tabular}{|l|l|l|}
17 & Sakit pada tangan kanan & $50,00 \%$ \\
\hline 18 & Sakit pada paha kiri & $25,00 \%$ \\
\hline 19 & Sakit pada paha kanan & $25,00 \%$ \\
\hline 20 & Sakit pada lutut kiri & $37,50 \%$ \\
\hline 21 & Sakit pada lutut kanan & $37,50 \%$ \\
\hline 22 & Sakit pada betis kiri & $25,00 \%$ \\
\hline 23 & Sakit pada betis kanan & $25,00 \%$ \\
\hline 24 & Sakit pada pergelangan kaki kiri & $25,00 \%$ \\
\hline 25 & Sakit pada pergelangan kaki kanan & $25,00 \%$ \\
\hline 26 & Sakit pada kaki kiri & $25,00 \%$ \\
\hline 27 & Sakit pada kaki kanan & $25,00 \%$ \\
\hline
\end{tabular}

Sumber : Pengolahan data 2019

Dari kuesioner Nordic body map didapatkan 6 segmen bagian tubuh yang mengalami keluhan sakit dengan persentasi lebih dari 50\%. Segemen-segmen tersebut antara lain ialah leher bagian atas, bahu kiri, bahu kanan, lengan atas kiri, lengan atas kanan, dan punggung.

\section{Penilaian Sudut Postur Tubuh Operator}

Proses penilaian pada sikap kerja di bagian reaching dimuai dari mengambil foto dengan kamera atau handphone. Gambar yang dihasilkan digunakan untuk mengetahui besar sudut dari masing-masing segmen tubuh. Pemberian sudut ini menggunakan aplikasi softwere autocad. Segmen tubuh yang diukur antara lain leher, punggung, kaki, lengan tas, lengan bawah, dan pergelangan tangan. Penilaian sudut dari postur kerja operator dapat dilihat pada gambar.

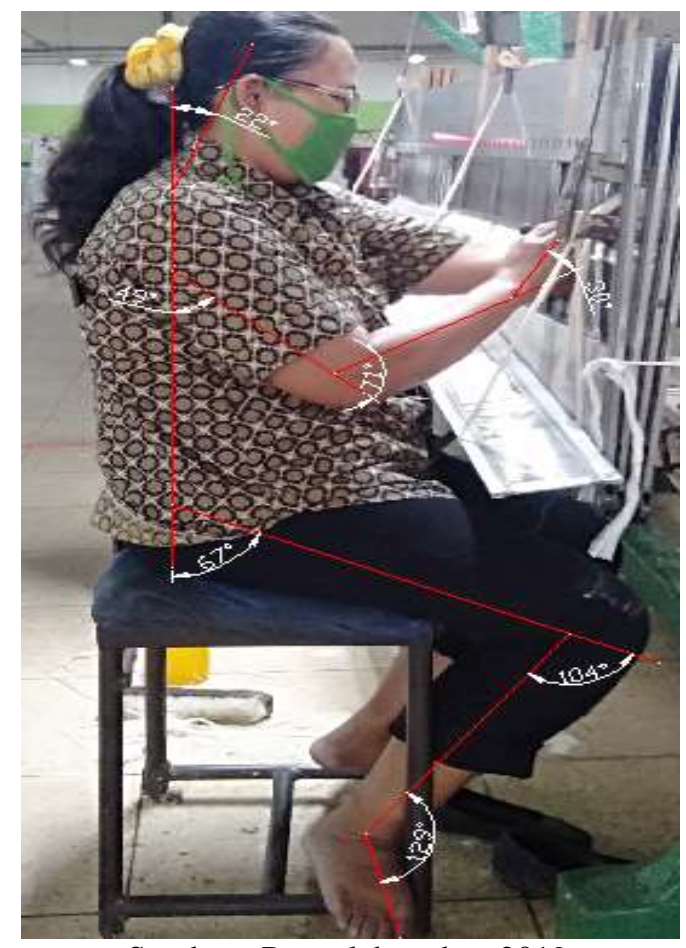

Sumber : Pengolahan data 2019

Ganbar. 5 Penilaian sudut Postur Kerja 


\section{Penilaian Grub A}

- Punggung (Trunk)

Dari gambar 5 diketahui bahwa punggung dalam posisi tegak atau lurus dengan sudut $180^{\circ}$, sehingga pada gambar 1 termasuk tegak. Berdasarkan gambar 1 skor punggung sebesar 1 .

- Leher (Neck)

Dari gambar 5 diketahui bahwa kepala dalam posisi menunduk dengan sudut $180^{\circ}-158^{\circ}=$ $22^{\circ}$, sehingga pada gambar 1 termasuk $>20^{\circ}$. Berdasarkan gambar 1 skor leher sebesar 2 . Tidak ada penambahan skor karena leher tidak memutar atau miring ke samping, sehingga skor leher sebesar $2+0=2$.

- Kaki (Leg)

Dari gambar 5 diketahui bahwa kaki dalam posisi duduk, sehingga pada gambar 1 termasuk kaki tertopang atau duduk dengan bobot rata-rata. Berdasarkan gambar 5 skor kaki sebesar 1 . Penambahan skor pada kaki karena lutut membentuk sudut $76^{\circ}$, sehingga skor kaki menjadi $1+2=3$

Penilaian skor pada tabel A mengguunakan tabel A pada REBA worksheet. Langkahlangkahnya sebgai berikut:

a) Hasil skor:

Punggung (trunk) $\quad: 1$

Leher $($ neck $) \quad: 2$

Kaki (leg) : : 3

b) Masukkan skor punggung, leher dan kaki pada tabel A REBA yang telah disediakan.

c) Tarik garis kebawah dan kekanan sampai bertemu pada satu angka.

d) Diketahui skor untuk REBA tabel A adalah 3

Berikut adalah hasil dari penilaian REBA tabel A dengan menggunakan tabel A.

Tabel 2. Skor Tabel A

\begin{tabular}{|c|c|c|c|c|c|c|c|c|c|c|c|c|c|}
\hline \multirow{2}{*}{\multicolumn{2}{|c|}{ Tabel A }} & \multicolumn{12}{|c|}{ Neck } \\
\hline & & \multicolumn{4}{|c|}{1} & \multicolumn{4}{|c|}{2} & \multicolumn{4}{|c|}{3} \\
\hline & Legs & 1 & 2 & 3 & 4 & 1 & 2 & 3 & 4 & 1 & 2 & 3 & 4 \\
\hline \multirow{5}{*}{ Trunk } & 1 & 1 & 2 & 3 & 4 & 1 & 2 & 3 & 4 & 3 & 3 & 5 & 6 \\
\hline & 2 & 2 & 3 & 4 & 5 & 3 & 4 & 5 & 6 & 4 & 5 & 6 & 7 \\
\hline & 3 & 2 & 4 & 5 & 6 & 4 & 5 & 6 & 7 & 5 & 6 & 7 & 8 \\
\hline & 4 & 3 & 5 & 6 & 7 & 5 & 6 & 7 & 8 & 6 & 7 & 8 & 9 \\
\hline & 5 & 4 & 6 & 7 & 8 & 6 & 7 & 8 & 9 & 7 & 8 & 9 & 9 \\
\hline
\end{tabular}

Sumber : Pengolahan data 2019

Setelah dilakukan penilaian untuk tabel A kemudian diberi penambahan dengan skor berat beban yang diangkat berdasarkan gambar 1 , operator tidak mengangkat benda atau $<5 \mathrm{~kg}$ sehingga mendapat skor 0 .

Skor tabel A dan penambahan berat beban adalah:

Nilai tabel $=3$

Nilai berat beban $\quad=0$

Total skor tabel A $\quad=3+0=3$

\section{Penilaian Grub B}

- Lengan atas (upper arm)

Dari gambar 5 diketahui bahwa sudut lengan atas kedepan terhadap sumbu tubuh sebesar $180^{\circ}-131^{\circ}=49^{\circ}$, sehingga pada gambar 2 termasuk $45^{\circ}-90^{\circ}$. Berdasarkan gambar 2 skor lengan atas sebesar 3 . Tidak ada penambahan skor pada lengan atas karena pundak atau bahu tidak ditinggikan, sehingga skor lengan atas sebesar $3+0=3$. 
- Lengan bawah (lower arm)

Dari gambar 5 diketahui bahwa sudut lengan bawah kedepan terhadap lengan atas sebesar $109^{\circ}$, sehingga pada gambar 2 termasuk $>100^{\circ}$. Berdasarkan gambar 2 skor lengan bawah sebesar 2.

- Pergelangan tangan (wrist)

Dari gambar 5 diketahui bahwa sudut pergelangan tangan sebesar $180^{\circ}-150=30^{\circ}$, sehingga pada gambar 2 termasuk $>15^{\circ}$. Berdasarkan gambar 2 skor pergelangan tangan sebesar 2. Penambahan skor pada pergelangan tangan karena pergelangan tangan menyimpang, sehingga skor pergelangan tangan sebesar $2+1=3$

Penilaian skor pada tabel B mengguunakan tabel B pada REBA worksheet. Langkahlangkahnya sebgai berikut:

a) Hasil skor:
Lengan atas (Upper arm) : : 3
Lengan bawah (Lower arm) : 2
Pergelangan tangan (Wrist) : 3

b) Masukkan skor lengan atas, lengan bawah, dan pergelangan tangan pada tabel B REBA yang telah disediakan.

c) Tarik garis kebawah dan kekanan sampai bertemu pada satu angka.

d) Diketahui skor untuk REBA tabel B adalah 5

Berikut adalah hasil dari penilaian REBA tabel B dengan menggunakan tabel B.

Tabel 3. Skor Tabel B

\begin{tabular}{|c|c|c|c|c|c|c|c|}
\hline \multirow{2}{*}{\multicolumn{2}{|c|}{ Tabel B }} & \multicolumn{6}{|c|}{ Low Arm } \\
\hline & & \multicolumn{3}{|c|}{1} & \multicolumn{3}{|c|}{2} \\
\hline & Wrist & 1 & 2 & 3 & 1 & 2 & 3 \\
\hline \multirow{6}{*}{ Upper Arm } & 1 & 1 & 2 & 2 & 1 & 2 & 3 \\
\hline & 2 & 1 & 2 & 3 & 2 & 3 & 4 \\
\hline & 3 & 3 & 4 & 5 & 4 & 5 & 5 \\
\hline & 4 & 4 & 5 & 5 & 5 & 6 & 7 \\
\hline & 5 & 6 & 7 & 8 & 7 & 8 & 8 \\
\hline & 6 & 7 & 8 & 8 & 8 & 9 & 9 \\
\hline
\end{tabular}

Sumber : Pengolahan data 2019

Setelah dilakukan penilaian untuk tabel B kemudian diberikan penambahan dengan skor pegangan atau genggaman berdasarkan gambar 2, operator menggenggam alat agak nyaman sehingga mendapat skor 1 .

Skor tabel B dan penambahan genggaman adalah:

$\begin{array}{ll}\text { Nilai tabel } & =5 \\ \text { Nilai berat beban } & =1 \\ \text { Total skor tabel B } & =5+1=6\end{array}$

Penentuan Skor Tabel C

Penilaian tabel $\mathrm{C}$ dilakukan dengan cara menggabunga skor yang diperoleh dari tabel $\mathrm{A}$ dan tabel $\mathrm{B}$ dengan menggunakan tabel $\mathrm{C}$.

Tabel $\mathrm{A}=3$

Tabel $\mathrm{B}=6$

Masukkan nilai yang diperoleh kedalam tabel $\mathrm{C}$ yang sudah di sediakan di worksheet. Tarik ke kanan dan kebawah hingga bertemu pada suatu angka. Sehingga skor dari tabel C adalah 5. Berikut pengerjaan pada tabel $\mathrm{C}$ ditunjukkan pada tabel sebagai berikut : 
Tabel 4. Skor Tabel C

\begin{tabular}{|c|c|c|c|c|c|c|c|c|c|c|c|c|c|}
\hline \multirow{2}{*}{\multicolumn{2}{|c|}{ Tabel C }} & \multicolumn{12}{|c|}{ Score B } \\
\hline & & 1 & 2 & 3 & 4 & 5 & 6 & 7 & 8 & 9 & 10 & 11 & 12 \\
\hline \multirow{12}{*}{ Score A } & 1 & 1 & 1 & 1 & 2 & 3 & 3 & 4 & 5 & 6 & 7 & 7 & 7 \\
\hline & 2 & 1 & 2 & 2 & 3 & 4 & 4 & 5 & 6 & 6 & 7 & 7 & 8 \\
\hline & 3 & 2 & 3 & 3 & 3 & 4 & 5 & 6 & 7 & 7 & 8 & 8 & 8 \\
\hline & 4 & 3 & 4 & 4 & 4 & 5 & 6 & 7 & 8 & 8 & 9 & 9 & 9 \\
\hline & 5 & 4 & 4 & 4 & 5 & 6 & 7 & 8 & 8 & 9 & 9 & 9 & 9 \\
\hline & 6 & 6 & 6 & 6 & 7 & 8 & 8 & 9 & 9 & 10 & 10 & 10 & 10 \\
\hline & 7 & 7 & 7 & 7 & 8 & 9 & 9 & 9 & 10 & 10 & 11 & 11 & 11 \\
\hline & 8 & 8 & 8 & 8 & 9 & 10 & 10 & 10 & 10 & 10 & 11 & 11 & 11 \\
\hline & 9 & 9 & 9 & 9 & 10 & 10 & 10 & 11 & 12 & 11 & 12 & 12 & 12 \\
\hline & 10 & 10 & 10 & 10 & 11 & 11 & 11 & 11 & 12 & 12 & 12 & 12 & 12 \\
\hline & 11 & 11 & 11 & 11 & 11 & 12 & 12 & 12 & 12 & 12 & 12 & 12 & 12 \\
\hline & 12 & 12 & 12 & 12 & 12 & 12 & 12 & 12 & 12 & 12 & 12 & 12 & 12 \\
\hline
\end{tabular}

Sumber : Pengolahan data 2019

Setelah dilakukan penilaian untuk tabel $\mathrm{C}$ kemudian diberikan penambahan dengan skor aktivitas berdasarkan gambar 3, operator mengalami pengulangan gerakan dalam waktu yang singkat (diulang lebih dari 4 kali per menit), sehingga memeprolah skor aktivitas 1 .

Skor tabel $\mathrm{C}$ dengan penambahan aktivitas sebagai berikut:

Skor tabel C : 5

Skor Aktivitas : 1

Total skor tabel C : $5+1=6$

\section{Penentuan Tingkat Risiko}

Penentuan tingkat risiko dapat di lihat pada gambar 4. Berdasarkan hasil perhitungan menggunakan metode REBA terhadap penilaian postur kerja pada operator diperoleh skor akhir tabel $\mathrm{C}$ yaitu 6 , yang artinya masuk dalam kategori level action 2 yaitu level risiko sedang dan perlu perbaikan untuk mengurangi risiko cidera pada operator reaching.

\section{KESIMPULAN}

Kesimpulan yang dapat diambil dari penelitian ini berdasarkan hasil analisis menggunakan metode REBA terhadap postur kerja operator reching menghasilkan nilai sebesar 6. Dengan tingkat risiko sedang dan memerlukan pencegahan untuk mengurangi risiko cidera.

\section{Saran}

Saran yang dapat diberikan dari hasil penelitian ini adalah :

1) Sebaiknya untuk pekerja melakukan aktivitas berdiri setiap kali 1 jam untuk melakukan peregangan.

2) Untuk peneliti selanjutnya diharapkan dapat merubah postur kerja yang baru sehingga dapat mengurangi keluhan secara fisik yang dirasakan oleh pekerja di bagian reaching. 


\section{DAFTAR PUSTAKA}

Catur, Muchamad S. (2012). Perbaikan Postur Kerja Dengan Merancang Ulang Meja Printing Menggunakan Metode REBA dan Pendekatan Biomekanik (studi kasus : PT Danar Hadi Santosa). Skripsi. Surakarta : Jurursan Teknik Industri, Universitas Sebelas Maret.

Hignett, Sue. Dan McAtamney Lynn. (1999). Rapid Entire Body Assessment (REBA). Jounal Applied Ergonomics 31 (2000) 201-205. Nottingham.

Kroemer K.H.E. Kroemer K.B, Kroemer K.E. (1994). Ergonomic : How to Design for Ease and Efficiency. Prentince Hall International. Inc. New Jersey.

Nurmianto, Eko. (1996). Ergonomi: Konsep Dasar dan Aplikasinya. Surabaya: Guna Widya.

Tarwaka, Solichul HA.B., Lilik S., (2004). Ergonomi untuk Keselamatan, Kesehatan Kerja dan Produktivitas. UNIBA Press. Surakarta

Wisanggeni, Bambang. (2010). Antropometri. Diakses tanggal 07 Agustus 2020. https://bambangwisanggeni.wordpress.com/2010/03/02/antropometri/. 